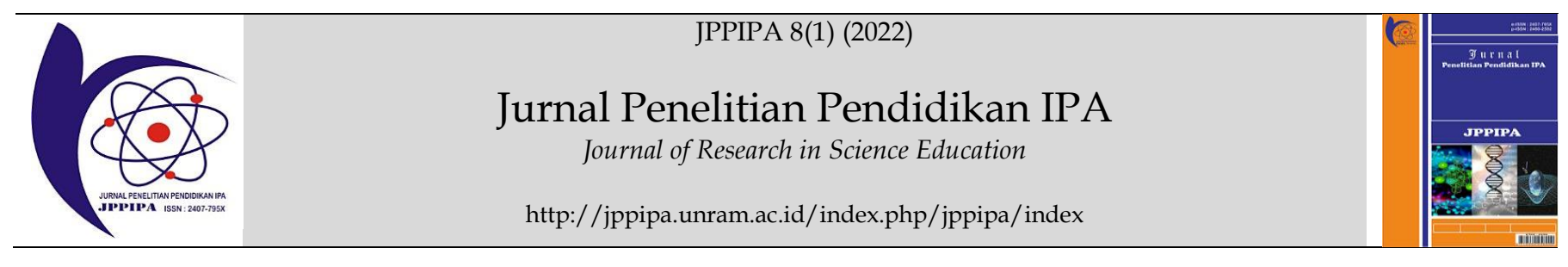

\title{
Content Analysis of Physics Textbooks for Senior High School on The Principle of Direct Current Circuits
}

\author{
Maria Fransiska Tunga ${ }^{*}$, Jumadi ${ }^{1}$ \\ ${ }^{1}$ Physics Education, Faculty of Mathematics and Natural Sciences, Universitas Negeri Yogyakarta, Yogyakarta, Indonesia.
}

DOI: $\underline{10.29303 / \text { ippipa.v8i1.1294 }}$

\section{Article Info}

Received: December 27, 2021

Revised: January 26, 2022

Accepted: January 28, 2022

Published: January 31, 2022

\begin{abstract}
This study aims to reveal the science process skills profile and the question type categories in physics textbooks for senior high school on the principle of direct current circuits. The research method in this study is descriptive analysis with a qualitativequantitative approach. The sample of this research is two physics textbooks that refer to the 2013 curriculum which is generally used as learning resources in Senior High schools in Indonesia. The determination of the sample in this study is based on the purposive sampling technique. The results showed that book A and book B already contained all aspects of Science Process Skills (SPS) although with different percentages. The results also showed that the aspect that appears the most is "observing" aspects of science process skills (SPS) which are $29.27 \%$ for book $\mathrm{A}$ and $36.36 \%$ for book B. The profile of questions shows that book $\mathrm{A}$ brings up a lot of C3 questions categories (applying), which are included in questions that do not require high reasoning in solving them. Other than that book B show that in book B there are many C4 questions categories (analyzing) which are included in questions that require high reasoning in solving them. Both books $\mathrm{A}$ and $\mathrm{B}$ do not present $\mathrm{C} 5$ (evaluating) and C6 (creating) questions categories that require high reasoning.
\end{abstract}

Keywords: Science process skills; Profile of questions; Content analysis; Direct current circuits; Physics textbooks

Citation: Tunga, M. F., \& Jumadi, J. (2022). Content Analysis of Physics Textbooks for Senior High School on The Principle of Direct Current Circuits. Jurnal Penelitian Pendidikan IPA, 8(1), 414-422. https://doi.org/10.29303/jppipa.v8i1.1294

\section{Introduction}

One of the challenges of the 21st century is competition between countries, especially in technology. Kumar (2013) and Prain (2012) stated that to be able to live in a good competition in the 21st century, young generations must at least own these abilities; communication skills, interpersonal relation, critical and rational thinking, problem-solving, risk-taking, cooperating skill, innovative skill, leadership, and technology.

Therefore, Indonesia needs to prepare human resources to master not only the technology needed but also all 21st-century skills. The quality of education, including in physics education, is expected to answer the challenges of the 21st century. High school physics lessons are closely related to textbooks as learning resources and references. The number of books circulating in the market, makes students have to be more selective in choosing books. In the 2016 BSNP, the government has set standards for the feasibility of the books, including the feasibility of content, presentation, language, and graphics.

Textbooks are one aspect that plays a major and important role in the learning process at school. Textbooks have a very strong influence on the learning process because they are one of the main sources for students to acquire knowledge. Textbooks can be the first and foremost interpreter of the vision and mission of education, books are also referred to as "shortcuts" in improving the quality of education. In addition to conveying coherence between the concepts of students'

\footnotetext{
*Email: mariafransiska.2021@student.uny.ac.id
} 
branches of knowledge, textbooks also play a role in spurring the development of intelligence, providing inspiration or ideas for students or teachers to explore more deeply about the topics presented. The quality of the textbooks, besides being a source of knowledge that can support the student learning process to be a success, can also guide and direct the teaching and learning process in the classroom towards a quality learning process as well. Books that are designed by the applicable curriculum and developed with a new paradigm will direct the learning process in the right direction according to the demands of the curriculum (Adisendjaja \& Oom, 2008). Until now, textbooks are still considered the most important teaching material. This can be seen from the fact that almost all educational institutions from elementary to a high level in general still use textbooks as the main teaching material. This also proves that the existence of textbooks is still an inseparable part of the learning process that takes place in various educational institutions today.

In the 2013 curriculum, it is written that students are expected to have scientific work competencies, which consist of formulating problems, proposing and testing hypotheses, determining variables, designing and conducting experiments, collecting and processing data, drawing conclusions, and communicating orally and in writing (Kemendikbud, 2016). Some of the competencies listed in the 2013 curriculum are science process skills competencies. Several studies have been conducted regarding the analysis of textbooks that focus on science process skills, such as research conducted by Shofia, et al., (2019), Virijai, et al., (2020), Putri, et al., (2020), Aliyah and Erman ( 2021). Overall, the results show that there are a few aspects of science process skills (SPS) in the book but it is not comprehensive. Considering that science process skills are one of the most crucial skills of the 21st century, so aspects of science process skills (SPS) are very important and crucial to be included in textbooks that are used in schools.

Science process skills are designed to provide an initial foundation for students to acquire new knowledge that supports the learning process at school. The research adopted the categorization of science process skills (SPS) according to the American Association for the Advancement of Science (AAAS, 1993) on Ongowo, et al (2013). According to this categorization, the basic science process skills comprise Inferring, observing, measuring, communicating, classifying, predicting. The aspects that exist in the adopted science process skills are specifically shown in Table 1.
Tabel 1. Science Process Skills

\begin{tabular}{|c|c|}
\hline Aspect & Description \\
\hline Observing & Using the five senses to classify objects \\
\hline Inferring & $\begin{array}{l}\text { Explanation of the result from } \\
\text { observations and data }\end{array}$ \\
\hline Measuring & $\begin{array}{l}\text { Using standard and nonstandard } \\
\text { measures to represent dimensions }\end{array}$ \\
\hline Communicating & $\begin{array}{l}\text { Using words or symbols to describe an } \\
\text { activity, object, or occasion }\end{array}$ \\
\hline Classifying & $\begin{array}{l}\text { Sorting, grouping, and arranging based } \\
\text { on }\end{array}$ \\
\hline Predicting & $\begin{array}{l}\text { similarities and differences } \\
\text { Revealing the outcome of a future event } \\
\text { based on a pattern of evidence }\end{array}$ \\
\hline
\end{tabular}

Science process skills (SPS) are thinking skills used to process information, solve problems, and form conclusions. Science process skills are the driving force for the discovery and development of facts and concepts as well as the development and development of attitudes and values. The importance of mastering science process skills by students to make it easier for students to understand abstract concepts if they learn through real objects and are carried out by students themselves through the learning process. Science process skills (SPS) are developed to acquire new knowledge and lead students to discover facts and concepts. Science process skills (SPS) are skills that need to be instilled, practiced, and possessed by students. If the student develops their science process skills, students capable to solve problems, thinking critically, making decisions, finding answers, helping students to think logically, ask questions in solving problems they face every day (Kurniawan, et al., 2019; Hernawati, et al., 2018; Gunawan, et al., 2019; Ekawati, et al., 2018; Wahyuni, et al., 2017; Derlina, 2016; Darmaji, et al., 2019; Prajoko, et al., 2017).

Therefore, the basic science process skills must be owned by students before they develop other skills. Fortunately, all these skills can be learned and obtained at school. To support science learning, students should not only learn facts, concepts, laws, and theories in science, but they should also learn the process of how products of science are created. Students should not only learn the products but the process, attitudes, and technology to truly understand science as a holistic (Mariana \& Praginda, 2009).

Science process skills should be used by teachers in the learning process to deliver teaching the facts of science effectively. This is because the science learning process is not just of knowledge but it is a way how to systematically understand the environment. Science process skills are required for students to learn about the world of science more specifically (Turiman, et al., 2012). In the science learning process, science process skills are used as to be teaching approach. Science process skills 
(SPS) can train students in the thinking process and scientific attitude. This is because the learning process is designed in such a way that students can meet the facts, concepts, and relate to the theory of using scientific process skills and attitudes of the students themselves. The science process skills are important for the discovery process, inquiry process, and thinking process which help students be lifelong learners (Farsakoglu, 2012; Cigrik \& Ozkan, 2015).

Textbooks containing science process skills are a means of supporting students to have scientific work competencies such as the 2013 curriculum. Marie and Al Heilah (2003) emphasize the importance of designing and producing school textbooks with content that meets scientific principles and educational standards because the content is one of the main components of any educational curriculum. Although textbooks occupy a basic position in the learning process, the efforts of educators both in developing textbooks and evaluating the contents of books continue to be carried out. Practice questions and questions containing assessment questions are considered as one of the important components of the content of the textbook. Skaker (1995) argues that to achieve a better level of thinking, students should be presented with questions that are more than just knowing facts. This supports the conclusion made by Bloom and his work assistants that certain types of questions lead to certain types of thinking (Bloom et al, 1989).

The results of the Trends in International Mathematics and Science Study (TIMSS) study in 2015 showed that students in Indonesia were ranked 44th out of 49 countries (Nizam, 2016). The form of the questions in TIMSS is multiple choice with 4 or answer choices, short entries, and descriptions. Short entries and descriptions are often called (constructed responses). TIMSS questions include questions that have medium and high complexity and require reasoning in solving them. Questions that usually have high reasoning are usually found on questions with a cognitive level of C4, C5, C6. Based on the results of the TIMSS study, it can be concluded that the reasoning ability of students in solving problems and critical thinking skills of students in Indonesia is still low. One of the factors suspected to be the cause is the lack of practice questions and questions in high school/MA Physics textbooks that raise aspects of C4 (analyzing), C5 (evaluating), C6 (creating). This is supported by Al-hasanat's research (2016) which found that in textbooks the categories of questions $\mathrm{C} 1$ and $\mathrm{C} 2$ are questions that do not require high reasoning in solving them because only cognitive processes of remembering and understanding are needed.

Bloom's taxonomy initially consisted of knowledge, understanding, application, analysis, synthesis, and evaluation. Along with the development of educational theory, Bloom's taxonomy was then revised by Krathwohl (2001) and psychologists of the flow of cognitivism to suit the times. The results of these improvements were published in 2001 under the name Revised Bloom's Taxonomy. The dimensions of the cognitive domain can be seen in Table 2 .

Tabel 2. Cognitive dimensions

\begin{tabular}{|c|c|c|}
\hline Type & $\begin{array}{l}\text { Revised Bloom's } \\
\text { Taxonomy }\end{array}$ & Description \\
\hline C1 & Remembering & $\begin{array}{l}\text { Recall relevant knowledge from } \\
\text { long-term memory }\end{array}$ \\
\hline $\mathrm{C} 2$ & Understanding & $\begin{array}{l}\text { Building meaning from the } \\
\text { learning message }\end{array}$ \\
\hline C3 & Apply & $\begin{array}{l}\text { Using procedures in certain } \\
\text { situations }\end{array}$ \\
\hline C4 & Analyzing & $\begin{array}{l}\text { Describe the parts and } \\
\text { determine their relationships }\end{array}$ \\
\hline C5 & Evaluating & $\begin{array}{l}\text { Make judgments based on } \\
\text { criteria and standards }\end{array}$ \\
\hline C6 & Creating & $\begin{array}{l}\text { Assembling elements to form a } \\
\text { functional unit }\end{array}$ \\
\hline
\end{tabular}

Hadi \& Novaliyosi, (2019) stated that students must be familiarized with high-order thinking skills (HOTS) questions. The researcher considers it important that all school textbooks including senior high school physics textbooks provide the types of assessment questions that match Bloom's Taxonomy. Therefore, it is necessary to analyze the types of questions presented in physics textbooks that are widely used in high school.

\section{Method}

This study uses descriptive analysis with a qualitative-quantitative approach. The research subjects in this study were physics textbooks for class XII which are generally used in SMA/MA. Sampling was done by the purposive sampling technique. The selected samples included: textbooks referring to the 2013 curriculum which were used as the main learning resources, namely books by Hary Subagya as book A and books by Marthen Kanginan as book B.

The data in this study is the principle of direct current circuits in the two textbooks analyzed. The data will be analyzed using descriptive statistical analysis techniques. In analyzing the data, the assessor examines the elements of science process skills (SPS) and the elements of the dimensions of the cognitive domain according to Bloom's taxonomy. The assessors consist of 3 experienced physics teachers. The analysis was carried out by calculating the percentage of aspects of science process skills or the percentage of elements of the dimensions of the cognitive domain according to Bloom's taxonomy that emerged from each textbook. The steps that must be taken are as follows: 
1. Counting all occurrences of science process skills aspects or revised bloom taxonomy type of each part of the book being analyzed.

2. Calculates the percentage occurrence aspects and type for each section of the book that is being analyzed. The percentage of each aspect category $(\mathrm{p})$ is calculated using the formula.

$$
p=\frac{\sum \text { indicators for each category }}{\sum \text { total indicator category }} \times 100 \% \text {. }
$$

(Sudijono, 2008)

3. Determining the reliability of observations.

The data was obtained in the form of a checklist from

3 observers on the science process skill aspect assessment sheet. Observers put a checkmark $(\checkmark)$ in the appropriate column. The format used is the format with the categories "yes" and "no". The data obtained were entered into the agreement contingency table.

4. Determining Coefficient of Deal.

After the agreement contingency table is filled, then it is entered into the formula. The numbers found as a match are the numbers in the cells that are diagonal to the sum of cells. Next, the numbers are entered into the formula Crude Index Agreement which is:

$$
C A=\frac{2 S}{N_{1}+N_{2}}
$$

Description:

\section{CA Coefficient of agreement}

$\mathrm{S}$ Agree, the same number of code for the same object

$\mathrm{N}$ Number of codes generated by each observer

5. Categorize the data obtained with the category of coefficient of agreement as follows:

$$
\begin{aligned}
& 0.81-1.00=\text { very high; } \\
& 0.61-0.80=\text { high; } \\
& 0.41-0.60=\text { enough; } \\
& 0.21-0.40=\text { low; } \\
& 0.01-0.02=\text { very low } .
\end{aligned}
$$

(Viera \& Garrett, 2005)

\section{Result and Discussion}

This study aims to reveal the profile of science process skills and the profile of questions in physics textbooks for senior high school on the principle of direct current circuits. The research method in this research is descriptive analysis with a qualitative-quantitative approach. The sample of this research is 2 physics textbooks referring to the 2013 Curriculum which are generally used as learning resources in Senior High schools in Indonesia. The determination of the sample in this study is based on the purposive sampling technique. The selected samples included: textbooks referring to the 2013 curriculum which were used as the major learning resources, namely books by Hary Subagya as book A and books by Marthen Kanginan as book B.

The initial step of this research is the documentation of the statements of the principle of direct current circuits from the two books contained in the explanation section, sample questions, and practice questions. These statements are analyzed and then determined based on the aspects of the science process skills (SPS) being developed. The student activity section was analyzed descriptively and what aspects of the science process skills (SPS) were developed through these activities.

This research was conducted using researcher triangulation, which involved three observers to research to test the credibility of the data. The data obtained in the form of a data checklist from the three observers are then entered into the agreement contingency table. The Coefficient of Agreement (CA) obtained is the result of the calculation of the Coarse Conformity Index formula. To determine the level of reliability of the research results, an agreement was made between researchers to determine the index of conformity between observers. After that, the data is processed into the form of frequency and percentage and presented in the form of tables and graphs for easy understanding. The data obtained were further

\begin{tabular}{|c|c|c|c|c|}
\hline & \multicolumn{4}{|c|}{ Observer 1, Observer 2} \\
\hline \multirow{4}{*}{ Observer 3} & & Agree & Disagree & $\begin{array}{l}\text { Number of } \\
\text { Analysis }\end{array}$ \\
\hline & Agree & 28 & - & 28 \\
\hline & Disagree & - & 13 & 13 \\
\hline & $\begin{array}{l}\text { Number of } \\
\text { Analysis }\end{array}$ & 28 & 13 & 41 \\
\hline
\end{tabular}
analyzed using content analysis to obtain research findings.

The recapitulation of the coefficient of agreement on the aspects of science process skills for each book is presented in Table 3 and Table 4.

Table 3. Contingency Agreement of Book A Observer

Based on the results of calculations using the

\begin{tabular}{|c|c|c|c|c|}
\hline & \multicolumn{4}{|c|}{ Observer 1, Observer 2} \\
\hline \multirow{4}{*}{ Observer 3} & & Agree & Disagree & $\begin{array}{l}\text { Number of } \\
\text { Analysis }\end{array}$ \\
\hline & Agree & 27 & - & 27 \\
\hline & Disagree & - & 6 & 6 \\
\hline & $\begin{array}{l}\text { Number of } \\
\text { Analysis }\end{array}$ & 27 & 6 & 33 \\
\hline
\end{tabular}
Coefficient of Agreement (CA) equation, the coefficient of agreement on aspects of SPS in book A is $68.29 \%$. This value when viewed in the category of agreement coefficient according to Viera \& Garrett (2005) is included in the "High" category.

Table 4. Contingency Agreement of Book B Observer 
Based on the results of calculations using the CA equation, the coefficient of agreement on the aspects of SPS in book B is $81.82 \%$. This value when viewed in the category of coefficient of agreement according to Viera \& Garrett (2005) is included in the "Very High" category.

The level of agreement on observations that have a Coefficient of Agreement (CA) value equal to 1 means that there is no difference of opinion regarding the appearance of indicators between the three observers in the textbook assessment. The level of agreement on observations that have a Coefficient of Agreement (CA) value not equal to 1 means that there are differences of opinion regarding the appearance of indicators between the three observers in the textbook assessment. Although there are differences of opinion regarding the emergence, the research results obtained are still included in the high and very high categories so that the data is suitable for use in research. As quoted by Fitriyah et al. (2017), states that data suitable for use in research must have an agreement coefficient value in the high or very high category.

\section{Science Process Skills (SPS)}

The percentage of occurrences of aspects of science process skills in book $\mathrm{A}$ is presented in Table 5 and the pie chart in Figure 1.

Table 5. Percentage of SPS Aspects in Book A

\begin{tabular}{lllll}
\hline SPS Aspect & \multicolumn{4}{l}{ The emergence of SPS $(\%)$} \\
\cline { 2 - 5 } & P1 & P2 & P3 & Average \\
\hline Observing & 29.27 & 26.83 & 31.71 & 29.27 \\
Inferring & 7.32 & 9.76 & 12.19 & 9.76 \\
Measuring & 9.76 & 4.88 & 12.19 & 8.94 \\
Communicating & 12.19 & 7.32 & 12.19 & 10.57 \\
Classifying & 9.76 & 7.32 & 12.19 & 9.76 \\
Predicting & 9.76 & 14.63 & 14.63 & 13.01 \\
\hline
\end{tabular}

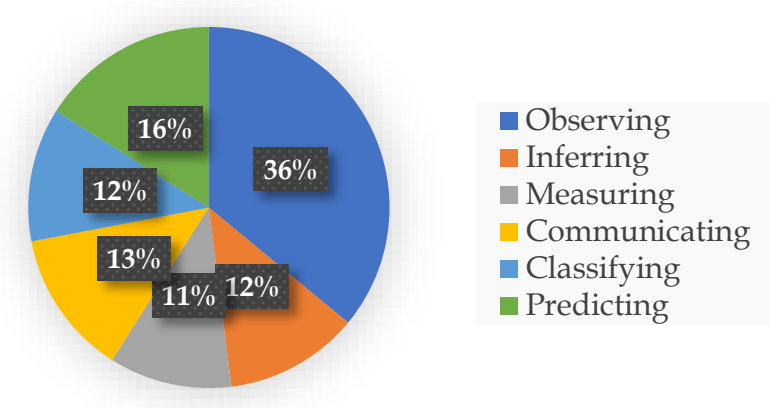

Figure 1. Percentage of SPS in Book A

The results of the analysis regarding the availability of science process skill categories in book A are generally shown in Table 5 and also presented in a pie chart in Figure 1. Based on the table, it can be seen that the occurrence of the "observing" aspect shows the highest average occurrence, which is $29.27 \%$. Based on the table, it can also be seen that book A already contains all aspects of Science Process Skills (SPS) although with different percentages. Overall, the textbook A studied can train students' science process skills in the aspects of observing, concluding, measuring, communicating, classifying, and predicting. The aspect that appears the most in book A is the aspect of observing. In book B, the percentage of occurrences of aspects of SPS in books is presented in Table 6 and a pie chart in Figure 2.

Table 6. Percentage of SPS Aspects in Book B

\begin{tabular}{lllll}
\hline SPS Aspect & \multicolumn{4}{l}{ The emergence of SPS $(\%)$} \\
\cline { 2 - 5 } & P1 & P2 & P3 & Average \\
\hline Observing & 36.36 & 39.39 & 33.33 & 36.36 \\
Inferring & 6.06 & 3.03 & 3.03 & 4.04 \\
Measuring & 12.12 & 12.12 & 12.12 & 12.12 \\
Communicating & 12.12 & 12.12 & 12.12 & 12.12 \\
Classifying & 24.24 & 18.18 & 21.21 & 21.21 \\
Predicting & 6.06 & 6.06 & 6.06 & 6.06 \\
\hline
\end{tabular}



Figure 2. Percentage of SPS in Book B

The results of the analysis of the availability of the science process skills category in book B are generally shown in Table 6 and also presented in a pie chart in Figure 2. Based on the table, it can be seen that the occurrence of the "observing" aspect shows the highest average occurrence, which is $36.36 \%$. Based on the table, it can also be seen that book A already contains all aspects of Science Process Skills (SPS), namely aspects of observing, concluding, measuring, communicating, and predicting even though the number of occurrences is different. Overall, the studied textbook B can train students' science process skills. The aspects that appear in book B are also dominated by SPS in the "observing" aspect by $36.36 \%$ and classifying by $21.21 \%$.

The results of this study indicate that the emergence of aspects of SPS from the two books analyzed in book $\mathrm{A}$ and book B is dominated by observing aspects. This is in line with the research conducted by Nurul Shofia et al (2019) which also found that the observing aspect was the dominant aspect that appeared the most in every textbook.

Based on Table 5 and Table 6, it can be seen that the emergence of science process skills (SPS) in each book shows a different percentage. The percentage of 
occurrences of the science process skills (SPS) aspect, when presented in the form of a bar chart, is shown in Figure 3.

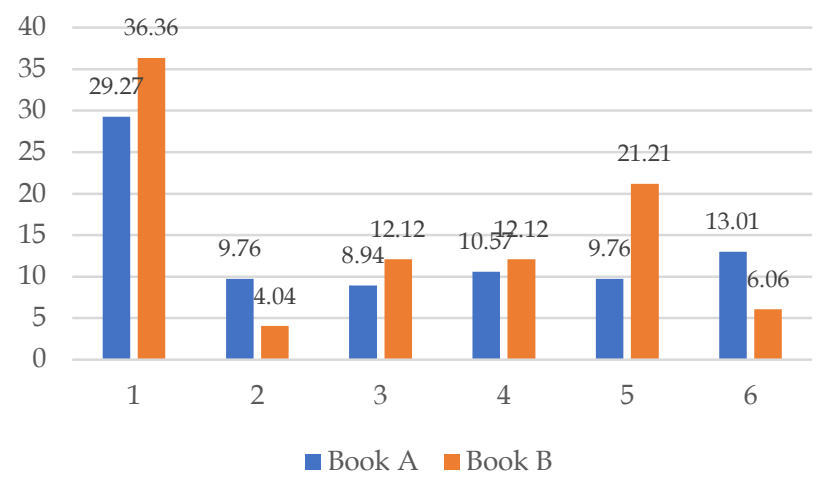

Figure 3. Comparison of the Percentage of SPS in Book A and Book B

Description:

1 = Observing

$2=$ Inferring

3 = Measuring

4 = Communicating

$5=$ Classifying

$6=$ Predicting

Based on the diagram, it can be seen that the two textbooks analyzed, namely, the Physics book by Hary Subagya as book A and the Physics book by Marthen Kanginan as book $B$ have reflected all science process skills (SPS) as required by the 2013 curriculum.

In addition to using textbooks as a source of knowledge for students, textbooks can also support them to practice basic science process skills (SPS), because both textbooks bring up many things that can train science process skills (SPS). Textbooks that have reflected science process skills (SPS) can train and encourage students to be able to build and improve SPS themselves.

\section{Question Type Categories}

The percentages of question type categories in book A are presented in Table 7, and the pie chart in Figure 4 respectively.

Table 7. Percentage of Question Type Categories in Book A

\begin{tabular}{lllll}
\hline Question Type & \multicolumn{5}{l}{ The emergence of QTC (\%) } \\
\cline { 2 - 5 } Categories & P1 & P2 & P3 & Average \\
\hline Remembering & 20 & 20 & 20 & 20 \\
Understanding & 20 & 10 & 10 & 13.33 \\
Apply & 40 & 40 & 50 & 43.33 \\
Analyzing & 20 & 30 & 20 & 23.33 \\
Evaluating & 0 & 0 & 0 & 0 \\
Creating & 0 & 0 & 0 & 0 \\
\hline
\end{tabular}

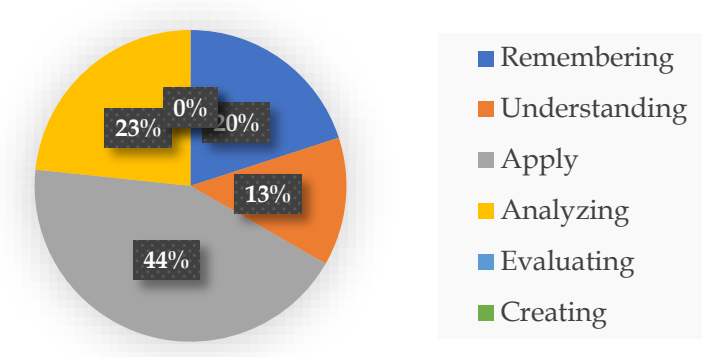

Figure 4. Percentage of Question Type Categories (QTC) in Book A

The results of the analysis of the types of questions in book A are shown in Table 7 and Figure 4. Based on the table, it can be seen that in book A there are many categories of questions C3 (applying), which are included in questions that do not require high reasoning in solving them. Questions C5 (evaluating) and C6 (creating) that require advanced reasoning are not given in the textbook. The percentages of question type categories in book A are presented in Table 8, and the pie chart in Figure 5.

Table 8. Percentage of Question Type Categories in Book B

\begin{tabular}{lllll}
\hline Question Type & \multicolumn{4}{l}{ The emergence of QTS (\%) } \\
\cline { 2 - 5 } Categories & P1 & P2 & P3 & Average \\
\hline Remembering & 8 & 12 & 4 & 8 \\
Understanding & 12 & 4 & 8 & 8 \\
Apply & 28 & 24 & 32 & 28 \\
Analyzing & 52 & 60 & 56 & 56 \\
Evaluating & 0 & 0 & 0 & 0 \\
Creating & 0 & 0 & 0 & 0 \\
\hline
\end{tabular}

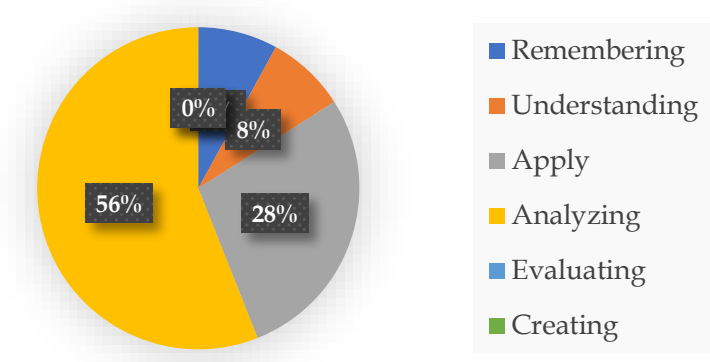

Figure 5. Percentage of Question Type Categories (QTC) in Book B

The results of the analysis of the types of questions in book B are shown in Table 8 and Figure 5 . Based on the table, it can be seen that in book B there are many categories of questions C4 (analyzing) which are included in questions that require high reasoning in solving them. In book B, the categories of questions C5 (evaluating) and C6 (creating) that require high reasoning are also not provided in the book.

Based on Table 7 and Table 8, it can be seen that the category of question types in each book shows different 
percentages. The percentage of question type categories (QTC), when presented in the form of a bar chart, is shown in Figure 6.

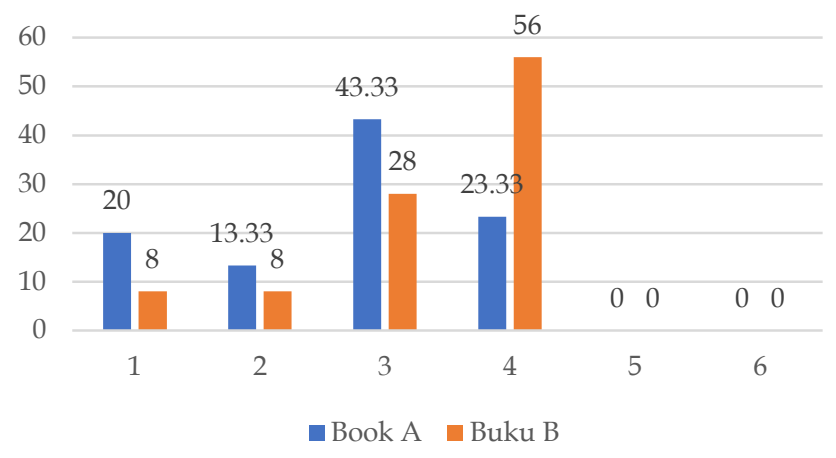

Figure 6. Comparison of the Percentage of Question Type Categories in Book A and Book B

Description:

$1=$ Remembering

$2=$ Understanding

$3=$ Apply

$4=$ Analyzing

$5=$ Evaluating

$6=$ Creating

Efforts to improve the reasoning ability of students can be trained through questions available in textbooks or textbooks with good quality questions. However, in reality, the two textbooks studied, namely book $\mathrm{A}$ and book B, still do not facilitate students to practice using high reasoning. This is because the questions given in textbooks are more dominant to train students at the level of applying and analyzing and have not provided questions with categories C5 (evaluating) and C6 (creating) which require high reasoning.

The results of this type of question category are in accordance with the research conducted by Juhanda (2016) which examined the collection of questions in the Electronic Biology School Book published in 2009. The results obtained in Juhanda's research (2016) also showed that the questions presented in the book were more dominant. on aspects of $\mathrm{C} 1$ and $\mathrm{C} 2$, these results are the same as research conducted by Al-hasanat (2016) which examined questions in Arabic textbooks found that in the textbooks studied, both types of questions were more dominant ( $\mathrm{C} 1$ and $\mathrm{C} 2)$ than other types of questions.

The uneven proportion of questions shows the weakness of the textbooks used, especially in encouraging students to use students' reasoning power such as creative, critical, and analytical thinking (Masduki, et al., 2013).

\section{Conclusion}

The results showed that in book A the appearance of the "observing" aspect showed the highest average occurrence, which was $29.27 \%$. Based on the results, it is also known that book A already contains all aspects of Science Process Skills (SPS) although with different numbers of occurrences. The results also show that the textbook B studied also contains all aspects of students' science process skills such as observing, concluding, measuring, communicating, and predicting aspects. The aspects that appear in book B are also dominated by science process skills in the "observing" aspect by $36.36 \%$ and classifying by $21.21 \%$.

The results of the analysis of the types of questions in the book A show that book A raises many categories of questions C3 (applying), which are included in questions that do not require high reasoning in solving them. Questions C5 (evaluating) and C6 (creating) that require advanced reasoning are not given in the textbook. The results of the analysis of the type of question categories in book B show that in book B there are many categories of questions C4 (analyzing) which are included in questions that require high reasoning in solving them. In book B, the categories of questions C5 (evaluating) and C6 (creating) that require high reasoning are also not provided in the book.

\section{References}

AAAS (American Association for the Advancement of Science) (1993). Benchmarks for scientific literacy: A Project 2061 report. New York: Oxford University Press. Retrieved from https://www.aaas.org/resources/benchmarksscience-literacy

Adisendjaja, Y. H., \& Oom, R. (2008). Analisis buku ajar biologi sma kelas $x$ di kota bandung berdasarkan literasi sains. Repository. Bandung: UPI.

Aliyah, A., \& Erman, E. (2021). Analisis Unsur-Unsur Keterampilan Proses Sains Dalam Buku IPA SMP. PENSA: E-Jurnal Pendidikan Sains, 9(2), 147153. Retrieved from https://ejournal.unesa.ac.id/index.php/pensa/ar ticle/view/37035

Cigrik, E., \& Ozkan, M. (2015). The investigation of the effect of visiting the science center on scientific process skills. Procedia-Social and Behavioral Sciences, 197, 1312-1316. https://doi.org/10.1016/j.sbspro.2015.07.405

Darmaji, D., Kurniawan, D. A., \& Irdianti, I. (2019). Physics Education Students' Science Process Skills. International Journal of Evaluation and Research 
in Education, 8(2),

293-298.

http://doi.org/10.11591/ijere.v8i2.16401

Derlina, D. (2016). Efek Penggunaan Model Pembelajaran Inquiry Training Berbantuan Media Visual dan Kreativitas terhadap Keterampilan Proses Sains Siswa. Cakrawala Pendidikan, (2), 87682. http://dx.doi.org/10.21831/cp.v15i2.8080

Ekawati, N. W., Iswari, R. S., \& Lisdiana, L. (2018). The Influence of Scientific Independence towards Students' Content Analysis and Science Process Skills on Cell Metabolism Topic. Jurnal Pendidikan IPA Indonesia, 7(4), 420-427. https://doi.org/10.15294/jpii.v7i4.16089

Farsakoğlu, C. F., Sahin, Ç., Karsli, F., Akpinar, A., \& Ultay, N. (2008). A Study on Awareness Levels of Prospective Science. World Applied Sciences Journal, 4(2), 174-182.

Fitriyah, M., DP, N. M., \& Yulianto, A. (2017). Content Analysis Of Value Of Character: A Case Study Of Physics Textbook In Rembang Regency. Unnes Science Education Journal, 6(3). https://doi.org/10.15294/usej.v6i3.20384

Gunawan, G., Harjono, A., Hermansyah, H., \& Herayanti, L. (2019). Guided Inquiry Model Through Virtual Laboratory To Enhance Students'science Process Skills On Heat Concept. Jurnal Cakrawala Pendidikan, 38(2), 259268. http://dx.doi.org/10.21831/cp.v38i2.23345

Hadi, S., \& Novaliyosi, N. (2019). TIMSS Indonesia (Trends in international mathematics and science study). In Prosiding Seminar Nasional \& Call For Papers. $\quad$ Retrieved from http://jurnal.unsil.ac.id/index.php/sncp/article/ view/1096

Hernawati, D., Amin, M., Irawati, M. H., Indriwati, S. E., \& Omar, N. (2018). The effectiveness of the scientific approach using encyclopedia as learning materials in improving students' science process skills in science. Jurnal Pendidikan IPA Indonesia, 7(3), 266272. https:// doi.org/10.15294/jpii.v7i3.14459

Juhanda, A. (2016). Analisis Soal Jenjang Kognitif Taksonomi Bloom Revisi pada Buku Sekolah Elektronik (BSE) Biologi SMA. Jurnal Pengajaran MIPA, 21(1), 61-66. https://doi.org/10.18269/jpmipa.v21i1.36258

Kanginan, M. (2018). Fisika untuk SMA/MA Kelas XII. Jakarta: Erlangga.

Krathwohl, D.R. (2002). A Revision of Bloom's Taxonomy: An Overview. Theory into Practice, 41(4): 212-218.

https://doi.org/10.1207/s15430421tip4104_2

Kumar, A. (2013). Twenty-first-century educational skills and restructuring of the education system: a view to ponder upon. International Journal of
Advancement in Education and Social Sciences, 1(1), 14.

Kurniawan, W., Darmaji, D., Astalini, A., Kurniawan, D. A., Hidayat, M., Kurniawan, N., and Farida, L. Z. N. (2019). Multimedia Physics Practicum Reflective Material Based on Problem Solving for Science Process Skills. International Journal of Evaluation and Research in Education, 8(4), 590-595. http://doi.org/10.11591/ijere.v8i4.20258

Marie, T., \& Alheilah, M. (2003). Modern educational Curricula. Almaserah Dar for Publishing and Distribution, Amman - Jordan.

Mariana, I. M. A., \& Praginda, W. (2009). Hakikat IPA dan pendidikan IPA. Bandung: PPPPTK IPA.

Nizam. (2016). Ringkasan Hasil-hasil Asesmen Belajar Dari Hasil UN, PISA, TIMSS, INAP. Puspendik

Ongowo, R. O., \& Indoshi, F. C. (2013). Science process skills in the Kenya certificate of secondary education biology practical examinations. Creative Education 04(11):713-717. http://dx.doi.org/10.4236/ce.2013.411101

Prain, V. (2012). Acting on sustainability. Research in Science Education, 42(1), 149-154.

Prajoko, S., Amin, M., Rohman, F., \& Gipayana, M. (2017). The Usage of Recycled Materials for Science Practicum: Is There Any Effect on Science Process Skills?. International journal of evaluation and research in education, 6(1), 1-8. http://doi.org/10.11591/ijere.v6i1.6340

Putri, B. S., Desnita, D., Asrizal, A., \& Darvina, Y. (2020). Analisis sajian buku teks pelajaran untuk memfasilitasi terlaksanaannya ketrampilan proses sains pada pembelajaran fisika kelas XII semester 2. Pillar Of Physics Education, 13(1). http://dx.doi.org/10.24036/8045171074

Shofia, N., Putra, N. M. D., \& Wahyuni, S. (2019). Analisis Konten Buku Teks Fisika SMA/MA Kurikulum 2013 pada Pokok Bahasan Alat Optik. UPEJ Unnes Physics Education Journal, 8(2), 178-191. https://doi.org/10.15294/upej.v8i2.33330

Skaker, F. (1995). Effectiveness of detective thought methods in teaching environmental education. PHO thesis, Damascus university.

Subagya, H. (2018). Konsep dan Penerapan Fisika SMA/MA Kelas XII. Jakarta: PT Bumi Aksara.

Sudijono. (2008). Pengantar Satistika Pendidikan. Jakarta: Raja Grafindo.

Turiman, P., Omar, J., Daud, A. M., \& Osman, K. (2012). Fostering 21st-century skills through scientific literacy and science process skills. Procedia-Social and Behavioral Sciences, 59, 110-116. https://doi.org/10.1016/j.sbspro.2012.09.253

Viera, A. J., \& Garrett, J. M. (2005). Understanding interobserver agreement: the kappa statistic. Fam 
med, 37(5), 360-363. Retrieved from https:// pubmed.ncbi.nlm.nih.gov/15883903/

Virijai, F., Asrizal, A., \& Desnita, D. (2020). Analisis integrasi aspek keterampilan proses sains (KPS) dalam buku teks pelajaran fisika sma kelas $\mathrm{X}$ semester 2. Pillar of Physics Education, 13(1). http://dx.doi.org/10.24036/8161171074

Wahyuni, S., Indrawati, I., Sudarti, S., \& Suana, W. (2017). Developing science process skills and problem-solving abilities based on outdoor learning in junior high school. Jurnal Pendidikan IPA Indonesia, 6(1).

http://dx.doi.org/10.15294/ipii.v6i1.6849 